\title{
Sarcoidosis Presenting with Pleural Involvement: A Case Report
}

\author{
Plevral Tutulumla Seyreden Sarkoidoz: Olgu Sunumu
}

Ali Kadri Çırak, Zeynep Öndeş, Nur Yücel

\begin{abstract}
Sarcoidosis is a multisystemic, granulomatous disease with particular involvement in the lungs and the intrathoracic lymph nodes. Pleural fluid has been reported to occur in $0 \%$ to $5 \%$ of the cases in the literature. Diagnosis depends on the presence of noncaseating granulomas in the biopsy sample and the exclusion of other possibilities. A 77-year-old woman with complaints of shortness of breath and a dry cough was found to have non-necrotizing granulomatous inflammation in pleural biopsy and computed tomography guided transthoracic Tru-Cut biopsy specimens. This was a rare case in which partial recovery was achieved through treatment with methylprednisolone for a year in reduced doses.
\end{abstract}

Key words: Sarcoidosis, pleural effusion, biopsy.

\section{Özet}

Sarkoidoz, nedeni bilinmeyen, en sık akciğerleri ve intratorasik lenf nodlarını tutan, multisistemik, nonkazeifiye granülomatöz bir hastalıktır. Literatürde plevra sıvısı görülme sıkığı \%0-5 arasında bildirilmektedir. Tanı plevra biyopsisinde kazeifikasyon nekrozu içermeyen granülom gösterilmesi ve granülom yapan diğer nedenlerin dışlanması ile konulur. Eforla nefes darlığı ve kuru öksürük şikayetleri olan 77 yaşındaki kadın hastamızın plevral biyopsi ve BT eşliğinde transtorasik tru-cut biyopsi örneklerinde "nekroz içermeyen granülomatöz enflamasyon" saptadık. Giderek azaltılan dozlarda bir yıllık metilprednisolon tedavisiyle tama yakın iyileşme sağladığımız olguyu nadir görülmesi nedeniyle sunuyoruz.

Anahtar Sözcükler: Sarkoidoz, plevral efüzyon, biyopsi.
Sarcoidosis is a multisystemic, non-caseating granulomatous disease with an unknown etiology that commonly affects the lungs and the intrathoracic lymph nodes (1). Sarcoidosis is generally seen in adults between 20 and 40 years of age, with a second peak evident in women over 50 (2). Diagnosis is made by evidence of non-necrotizing granulomas histopathologically, together with clinical and radiological findings. Pleural involvement in sarcoidosis is rare, but pleural fluid, pneumothorax, pleural thickening and nodules, hydropneumothorax, and chylothorax may be seen (3). Clinically significant pleural involvement is found in $2 \%$ to $4 \%$ of the patients (4). It is usually a paucicellular, lymphocyte-predominant exudate, with a pleural fluid/serum protein ratio that is more consistently in the exudative range based on the pleural fluid lactate dehydrogenase (LDH) criterion. A definitive diagnosis is made with finding of granuloma that does not include caseous necrosis in the pleural biopsy and exclusion of other reasons for granuloma (4).
Department of Chest Diseases, Health Sciences University, İzmir Dr. Suat Seren Chest Diseases and Surgery Training and Research Hospital, İzmir, Turkey
Sağlık Bilimleri Üniversitesi İzmir Dr. Suat Seren Göğüs Hastalıkları Ve Cerrahisi Eğitim Ve Araştırma Hastanesi, Göğüs Hastalıkları Kliniği, İzmir

Submitted (Başvuru tarihi): 28.07.2017 Accepted (Kabul tarihi): 05.09.2017

Correspondence (iletişim): Ali Kadri Çırak, Department of Chest Diseases, Health Sciences University, İzmir Dr. Suat Seren Chest Diseases and Surgery Training and Research Hospital, İzmir, Turkey

e-mail: alikadri.cirak@saglik.gov.tr 


\section{CASE}

A 77-year-old female patient presented with shortness of breath and a dry cough, which had increased over 2 months. She didn't smoke and there was no other known disease. Her physical examination revealed diminished lung sounds in the right hemithorax. No pathological finding was disclosed in the biochemistry and complete blood count; the erythrocyte sedimentation rate was 36 $\mathrm{mm} /$ hour. An electrocardiogram showed a normal sinus rhythm and a tuberculin skin test was negative. Her chest radiogram revealed pleural effusion in the right side, and an increase in non-homogenous density in the right middle zone (Figure 1). Thorax CT examination revealed massive lesions at the level of the right upper lobe bronchus and atelectasis density enhancement around the lesion, a consolidation area (atelectasis) involving air bronchograms in the middle lobe, pleural fluid in the right hemithorax, and a subcarinal lymph node $13 \mathrm{~mm}$ in diameter (Figure 2). Positron emission tomography/computed tomography (PET-CT) examination showed pathologically increased fluorine-18 fluorodeoxyglucose uptake in the right paratracheal (SUVmax: 4.9) and subcarinal (SUVmax: 6.0) lymph nodes in the right upper lobe mass lesion (SUVmax: 13.1).

Lung cancer involving the mediastinum and pleural metastasis was considered clinically and radiologically. Thoracentesis was performed. The pleural fluid biochemistry was compatible with exudative fluid and the adenosine deaminase level was $10 \mathrm{U} / \mathrm{l}$ (Table 1). Cytological examination of the pleural fluid revealed lymphocyte cells. Examination of the mass lesion in the lung and subcarinal lymph node with fiberoptic bronchoscopy and endobronchial ultrasound-guided fine-needle aspiration (EBUSFNA) were not diagnostic. Non-necrotizing granuloma compatible with sarcoidosis was detected in a sample of the Tru-Cut biopsy taken from the mass lesion in the lung with CT guidance (Figure 3). Abrams biopsy sample taken to determine pleural fluid etiology revealed nonnecrotizing granulomatous pleuritis compatible with sarcoidosis. (Figure 4).

Pleural fluid, bronchial aspiration, bronchoalveolar lavage, EBUS-FNA and CT-guided transthoracic Tru-Cut specimens were found to be negative in acido-resistant bacilli smear and culture.

The blood angiotensin-converting enzyme (ACE) level was $60 \mathrm{U} / \mathrm{I}$ (normal: 8-52 U/I), serum calcium level was 9.5 $\mathrm{mg} / \mathrm{dL}$ (normal: $8.6-10 \mathrm{mg} / \mathrm{dL}$ ), and 24-hour urinary calcium was $125 \mathrm{mg} / 24$ hours (normal: $42-353 \mathrm{mg} / 24$ hours). Ophthalmological examination was normal. Spi- rometric evaluation was forced expiratory volume in one second (FEV1): 1.40 L (85\%), forced vital capacity (FVC): $1.50 \mathrm{~L}(75 \%), \mathrm{FEV} 1 / \mathrm{FVC}: 88 \%$, and diffusing capacity of the lung for carbon monoxide (DLCO): 15.4 $\mathrm{mL} / \mathrm{mmHg} /$ minute (48\%).

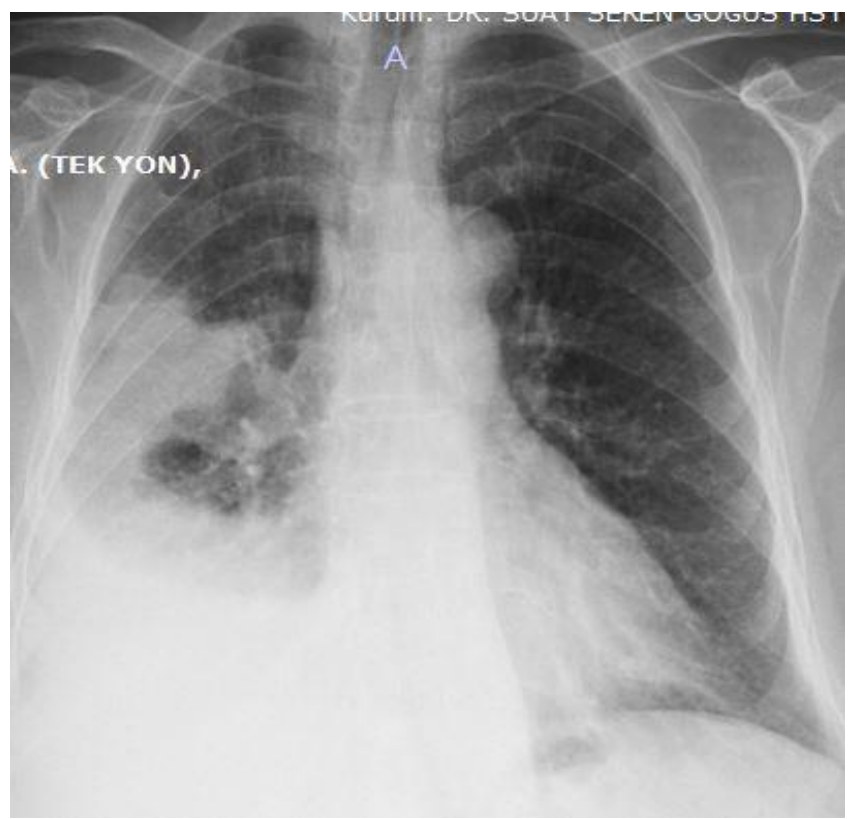

Figure 1: Posterior anterior chest $X$-ray revealed bilateral hilar enlargement, pleural effusion and parenchymal infiltration at the left upper zone

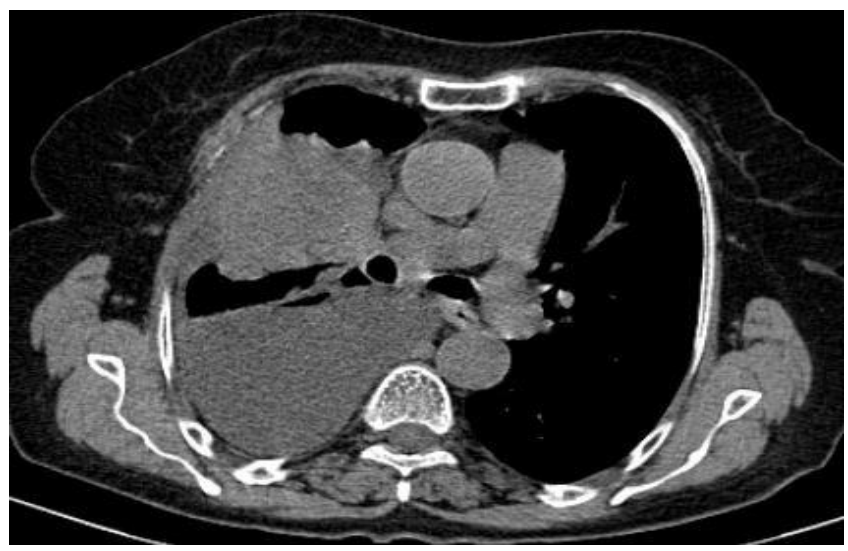

Figure 2: Thoracic CT findings

Tablo 1: Biochemichal parameters of serum and pleural fluid of case

\begin{tabular}{|l|c|c|}
\hline Total protein $(\mathrm{g} / \mathrm{dl})$ & Serum & Pleural fluid \\
\hline $\mathrm{LDH}(\mathrm{U} / \mathrm{L})$ & 7,1 & 5,2 \\
\hline $\mathrm{ADA}(\mathrm{U} / \mathrm{L})$ & 153 & 156 \\
\hline ACE $(\mathrm{U} / \mathrm{L})$ & $\mathrm{NA}$ & 10 \\
\hline Calcium $(\mathrm{mg} / \mathrm{dl})$ & 60 & $\mathrm{NA}$ \\
\hline Eryrocyte sedimentation rate $(\mathrm{mm} / \mathrm{h})$ & 36 & $\mathrm{NA}$ \\
\hline
\end{tabular}

LDH: Lactate dehydrogenase, ADA: Adenosin deaminase, ACE: Angiotensin converting enzyme, NA: not applicable 
Symptomatic stage II lung and pleural sarcoidosis was diagnosed. Methylprednisolone $(0.5 \mathrm{mg} / \mathrm{kg} /$ day $)$ was initiated and the dose was gradually reduced. Clinical radiological improvement (Figure 5 and 6) was observed during follow-up and at the first year of treatment.

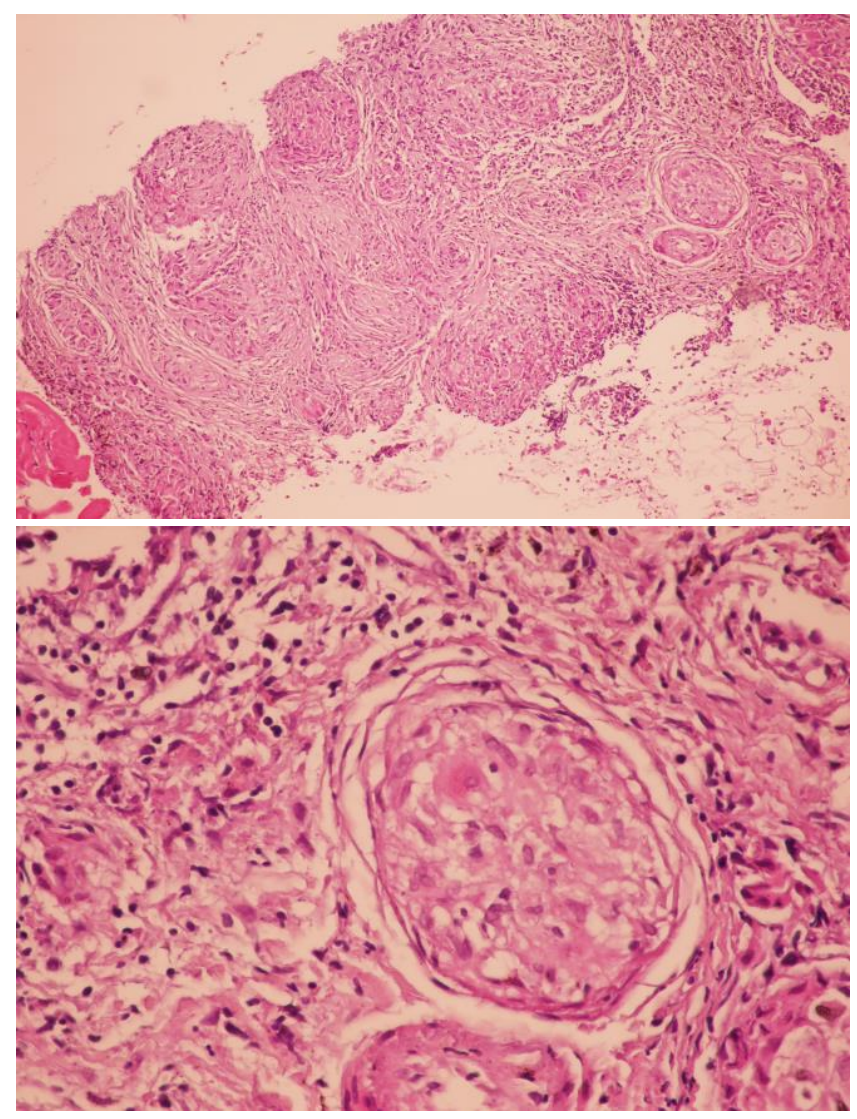

Figure 3: Presence of non-necrotizing granuloma on tru-cut lung biopsy (H\&E, $\times 100$ and $\times 400)$

\section{DISCUSSION}

Sarcoidosis is an idiopathic multisystemic granulomatous disease, which frequently involves the bilateral lymph nodes, pulmonary parenchyma, and eye and skin lesions (1). Pleural involvement is quite rare, though Schaumann wrote the first report on this entity in 1933 (5). It is not entirely certain why pleural involvement is scarce, despite the fact that pulmonary parenchymal and nodal involvement is present in almost all reported cases. The reasons could be multifactorial: (a) the mere presence of pleural effusion associated with sarcoidosis cannot be considered to be caused by sarcoidosis, (b) small pleural effusions can be missed on routine chest X-rays, (c) in a tuberculosis endemic country like ours, most pleural effusions are incorrectly diagnosed as tubercular and empirically treated with anti-tuberculosis therapy, and hence missed, (d) a lack of histopathological evidence of pleural involvement, or (e) a lack of awareness regarding this rare manifesta- tion leading to the diagnosis being missed. Pleurisy in sarcoidosis has been considered to be related to either inflammation of the visceral and parietal pleura caused by peripheral lung granulomas, or a disturbance of the venous and lymphatic circulations. It is typically a paucicellular, lymphocytic-predominant, and protein discordant exudate with low LDH, further supporting the view of increased capillary permeability with minimal pleural space inflammation being the causative mechanism in the formation of pleural fluid in sarcoidosis and reinforcing the hypothesis of a few advocates of a "protective pleural mechanism" keeping pleural spaces dry (6).

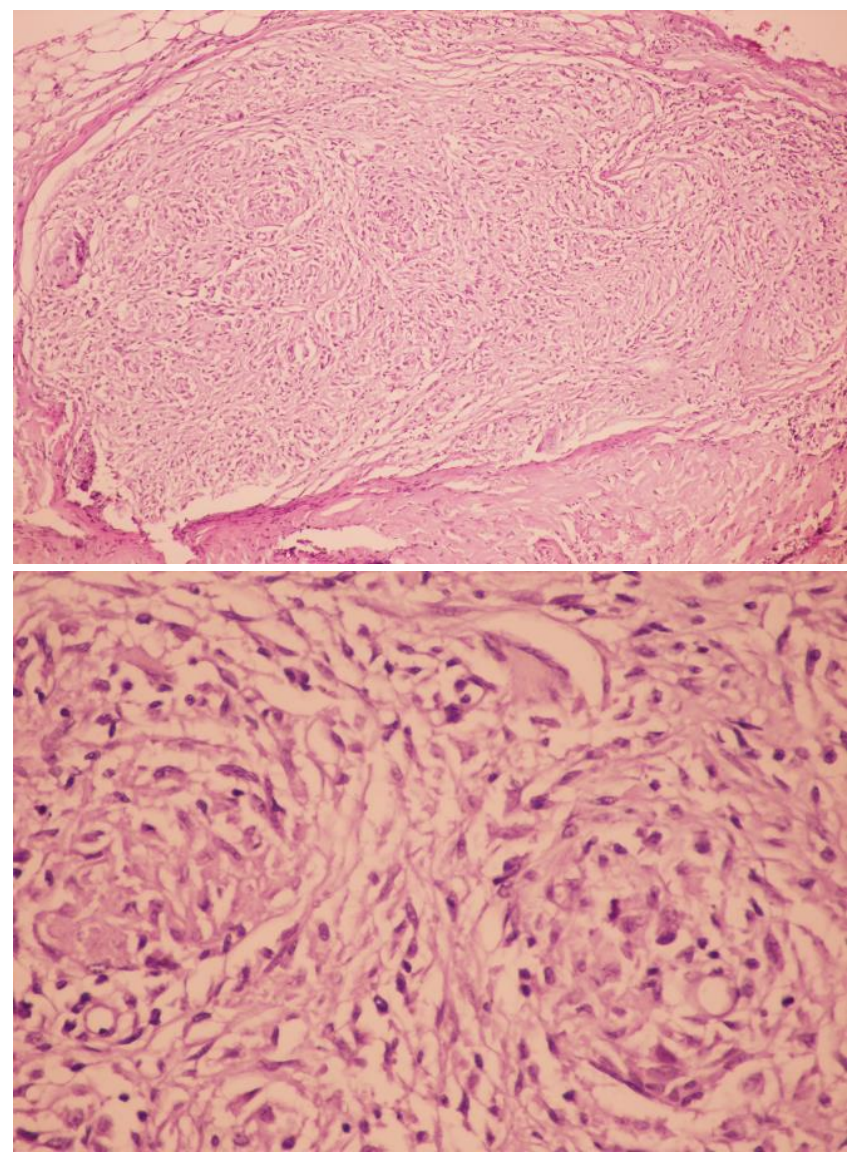

Figure 4: Presence of non-necrotizing granuloma on tru-cut lung biopsy (H\&E, $x 100$ and $x 400$ )

Sarcoidosis-related pleural fluid may be completely asymptomatic; however, some patients may suffer from severe dyspnea and/or pleuritic chest pain (6). The current patient's complaint was dyspnea.

Sarcoidosis-related pleural effusion is slightly more common on the right side and is usually an exudate with lymphocytic predominance $(7,8)$. The findings of our case were similar to those seen in the literature.

Information in the literature is limited regarding the ACE level in sarcoidosis-related pleural effusion (9). In the current case, as sarcoidosis was not initially considered 
clinically and radiologically, the pleural ACE level was not examined.

Pleural involvement is more frequently seen in stage II and III sarcoidosis patients $(10,11)$. Our patient was at stage II of the disease. The exact diagnosis of pleural involvement in sarcoidosis and the differential diagnosis with other causes of granulomatous pleuritis depend on the pathological findings in pleural biopsies obtained with a closed pleural biopsy, medical thoracoscopy, or videoassisted thoracoscopic surgery (4). We obtained a pleural tissue specimen using an Abrams biopsy.

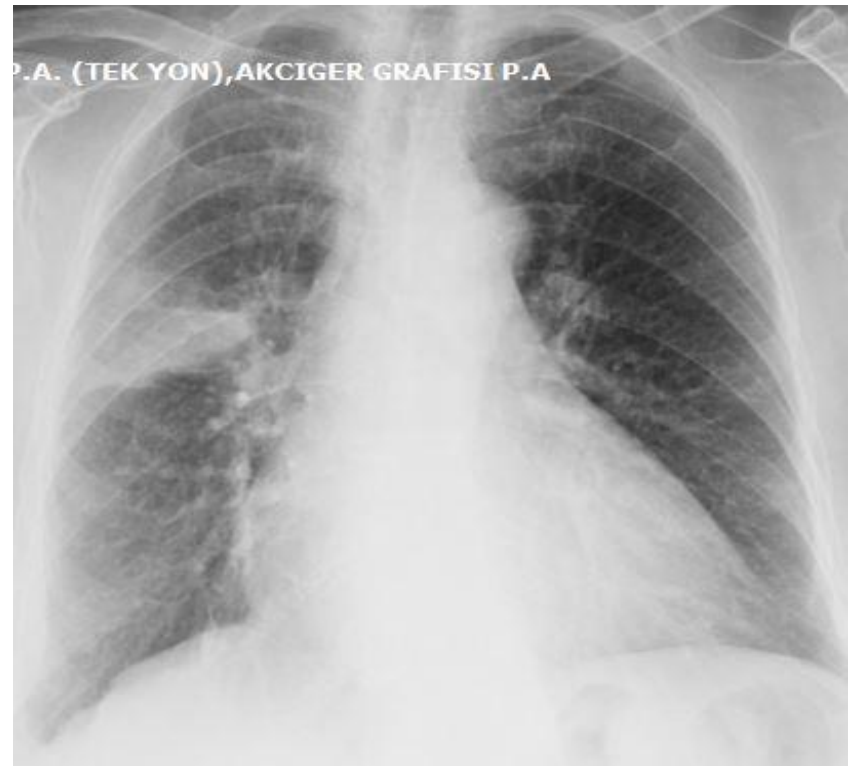

Figure 5: Control posterior anterior chest $X$-ray

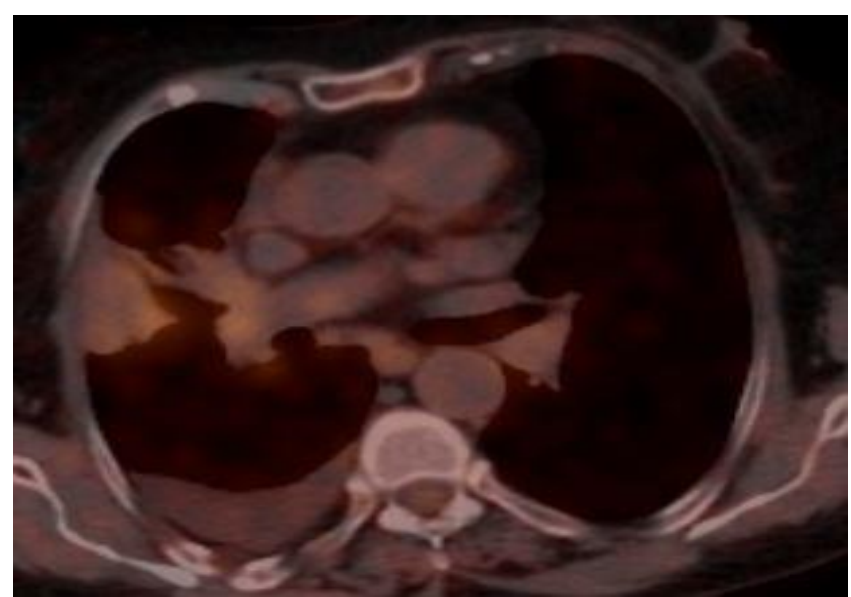

Figure 6: Control PET/CT findings

According to the literature, sarcoid pleural effusions may resolve spontaneously or require corticosteroids for resolution. The length of time for spontaneous resolution varies, but most resolve in 1 to 3 months. If the effusion is symptomatic and recurrent, steroid therapy is recommended for symptomatic relief and to hasten the resolution of the effusion. Decortication has been successful in relieving dyspnea in a patient who had lung entrapment from sarcoidosis $(11,12)$. Clinical-radiological improvement was achieved with steroid therapy in our case.

The current case was presented to highlight the possibility of sarcoidosis in patients with pleural effusion. However, other pleural pathologies should be excluded and the diagnosis confirmed by biopsy.

\section{CONFLICTS OF INTEREST}

None declared.

\section{AUTHOR CONTRIBUTIONS}

Concept - A.K.Ç., Z.Ö., N.Y.; Planning and Design A.K.Ç., Z.Ö., N.Y.; Supervision - A.K.Ç., Z.Ö., N.Y.; Funding -; Materials - N.Y., Z.Ö.; Data Collection and/or Processing -; Analysis and/or Interpretation - N.Y.; Literature Review - N.Y.; Writing - A.K.Ç., Z.Ö., N.Y.; Critical Review - A.K.Ç.

\section{YAZAR KATKILARI}

Fikir - A.K.Ç., Z.Ö., N.Y.; Tasarım ve Dizayn - A.K.Ç., Z.Ö., N.Y.; Denetleme - A.K.Ç., Z.Ö., N.Y.; Kaynaklar -; Malzemeler - N.Y., Z.Ö.; Veri Toplama ve/veya İşleme -; Analiz ve/veya Yorum - N.Y.; Literatür Taraması - N.Y.; Yazıyı Yazan - A.K.Ç., Z.Ö., N.Y.; Eleştirel Inceleme A.K.Ç.

\section{REFERENCES}

1. Salerno D. Sarcoidosis pleural effusion: a not so common feature of a well-known pulmonary disease. Respir Care 2010; 55:478-80.

2. Mihailovic-Vucinic $V$, Jovanovic D. Pulmonary sarcoidosis. Clin Chest Med 2008; 29:459-73. [CrossRef]

3. Scadding JG, Mitchell DN. Sarcoidosis. 2nd ed. Chapman \& Hall, London, 1985.

4. Lynch JP 3rd, Kazerooni EA, Gay SE. Pulmonary sarcoidosis. Clin Chest Med 1997; 18:755-85.

5. Schaumann MJ. Etude anatomo-patholgique et histologique surles localizations vicerales de la lymphogranulomatose benigne. Bull Soc Fr Dermatol Syphiligr 1933; 40:1167-78.

6. Soskel NT, Sharma OP. Pleural involvement in sarcoidosis. Curr Opin Pulm Med 2000; 6:455-68. [CrossRef]

7. Costabel U, Hunninghake GW. ATS/ERS/WASOG statement on sarcoidosis. Sarcoidosis Statement Committee. American Thoracic Society. European Respiratory Society. World association for sarcoidosis and other granulomatous disorders. Eur Respir J 1999; 14:735-7. 
8. Nusair S, Kramer MR, Berkman N. Pleural effusion with splenic rupture as manifestations of recurrence of sarcoidosis following prolonged remission. Respiration 2003; 70:1 14-7. [CrossRef]

9. Bedrossian CW, Stein DA, Miller WC, Woo J. Levels of angiotensin-converting enzyme in pleural effusion. Arch Pathol Lab Med 1981; 105: 345-6.
10. Huggins JT, Doelken $P$, Sahn SA, King L, Judson MA. Pleural effusions in a series of 181 outpatients with sarcoidosis. Chest 2006; 129:1599-604. [CrossRef]

11. Özışık NÇ, Yurteri G, Demirkök SS. Re-evaluation of our sarcoidosis patients because of three pleural sarcoidosis cases. Solunum 2009; 11: 125-129

12. Cohen M, Sahn SA. Resolution of pleural effusions. Chest 2001; 119:1547-62. [CrossRef] 